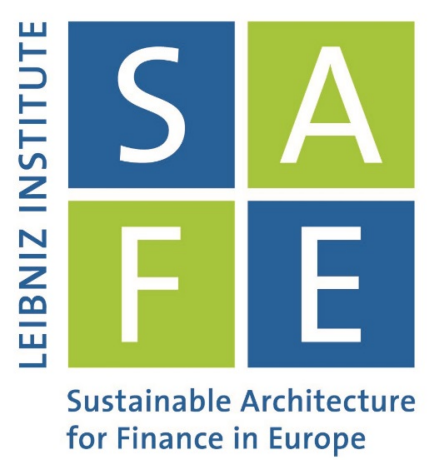

Sandra Eckert

\title{
EU Agencies in Banking and Energy Between Institutional and Policy Centralisation
}

SAFE Working Paper No. 278

\section{Leibniz Institute for Financial Research SAFE}




\title{
EU agencies in banking and energy between institutional and policy centralisation
}

\author{
AUTHOR \\ Sandra Eckert \\ Aarhus Institute of Advanced Studies, Aarhus University, Aarhus, Denmark \\ LEIBNIZ Institute for Financial Research SAFE (Sustainable Architecture for Finance in \\ Europe), House of Finance, Goethe University Frankfurt, Germany \\ Department of Social Sciences, Goethe University Frankfurt, Germany
}

\section{CONTACT INFORMATION}

Sandra Eckert

AIAS-COFUND Fellow, Associate professor

Aarhus Institute of Advanced Studies

Høegh-Guldbergs Gade 6B

building 1630, 116

8000 Aarhus C

Denmark

saneck@aias.au.dk

\begin{abstract}
This working paper suggests to analyse agencification as a double process of institutional and policy centralisation. To that end, it develops a categorisation of agencies that incorporates these two dimensions. More specifically, it is argued that mixed outcomes where the levels of institutional and policy centralisation diverge can be expected to be the rule rather than the exception, in line with the hybrid nature of EU agencies as inbetweeners. Moreover, the fiduciary setting hits important legal constraints given the limits to delegation in the EU context. Against this backdrop a process whereby institutional centralisation develops incrementally and remains limited, yet is accompanied by a process of substantial policy centralisation, appears as the most promising path for EU agencification. A fiduciary setting, where a strong agency enjoys a high degree of independence and operates in a centralised policy space, by contrast, should be the exception. The comparative study of the process of agencification in the energy and banking sector is insightful in the light of these expectations. The incremental nature of institutional change in energy exemplifies the usual path of agencification, which is conducive to a weak agency operating in a relatively centralised policy space. Agencification in banking, by contrast, has led to a rather unusual outcome where the strong agency model combines with a fragmented policy context.
\end{abstract}

\section{KEYWORDS}

agency, banking, centralisation, energy, fiduciary, electricity, policy 


\section{FUNDING \& ACKNOWLEDGEMENTS}

Previous research on energy regulation conducted between 2004 and 2008 on which this article draws was financed by the European Union's Sixth Framework Programme (FP6-CITIZENS, New Modes of Governance NEWGOV, grant agreement ID 506392, Project 5 "New Modes of Governance in the Shadow of Hierarchy"). Research conducted in 2019 on banking and energy regulation has been supported by the LOEWE Center on Sustainable Financial Architecture for Europe (Project "The State of the Union: The Politics of Integration in Banking and Energy", SAFE funding agreement \#21136) at the House of Finance, Goethe University Frankfurt. The paper has been written and researched when holding a COFUND-AIAS fellowship (European Union Horizon 2020 Research and Innovation Programme Marie Sklodowska-Curie grant agreement no 754513 and Aarhus University Research Foundation) awarded by the Aarhus Institute of Advanced Studies (AIAS).

A previous version of this paper was presented during the TARN workshop EU Agencies as 'Inbetweeners'? The Relationship between EU Agencies and Member States held on 4 and 5 December 2019 in Maastricht. I would like to express my gratitude to all participants who have provided extremely helpful comments during the workshop, and to the editor of the TARN working paper series Jarle Trondal for his advice and guidance. Special thanks go to the interview partners who have been willing to devote their time to my research and share their experience in energy and banking regulation. 


\section{Introduction}

Agencification in the European Union (EU) is a phenomenon studied widely (for an overview see Egeberg and Trondal, 2016) both by political scientists and legal scholars. Political scientists have addressed issues such as the relationship between regulatory networks and agencies (Levi-Faur, 2011; Tarrant and Kelemen, 2017; Blauberger and Rittberger, 2015; Groenleer, 2011; Coen and Thatcher, 2008; Maggetti and Gilardi, 2011), or the question of agency independence and autonomy (Wonka and Rittberger, 2010; Ossege, 2015; Groenleer, 2009). Legal analysis has brought to the fore treaty-based constraints to agencification and engaged in an intense discussion of relevant case law (Chamon, 2016; Vos, 2018a). One research question which is at the heart of academic enquiry in both disciplines is about where we ought to locate these agencies in the EU's multi-level space. As in European integration theory more generally, a line can be drawn between a supranational and intergovernmental image of EU agencies(Egeberg and Trondal, 2017: 676-677)g. European law experts have, moreover, posited that it is most accurate to consider EU agencies as "inbetweeners" in order to acknowledge their "hybrid" positioning between the member states and the supranational level (Vos, 2018a; Everson et al., 2014). This working paper seeks to systematically map institutional settings while also taking into account the policy space in which EU agencies operate. A case comparison of banking and energy is used to illustrate the value added of this analytical lens.

\section{Making sense of EU-agencification: institutional and policy centralisation}

Morten Egeberg and Jarle Trondal have identified three conceptual images in their stock-taking of the literature on EU agencies, namely intergovernmentalism, transnational technocracy, and supranationalism. Moreover, they differentiate between a rational choice, institutional or organisational approach (Egeberg and Trondal, 2016; Egeberg and Trondal, 2017). This paper adopts an institutional approach while also considering the agencies' policy context.

\section{Institutional structure - from networked to centralised agency}

Mark Thatcher's and David Coen's historical institutionalist take presents agencification as an incremental process of institutional layering. Their conceptual framework allows us to take stock of regulatory cooperation in the order of augmenting centralisation (Thatcher and Coen, 2008: 811-812, summarised in Table 1): Informal network of independent regulatory authorities 
or IRAs (NIRA), European Network of Regulators (ERN), European Regulatory Agency (ERA), Federal European Regulatory Agency (FERA), and a Single European Regulator (SER). Thatcher and Coen find, at the time of writing in 2008, that the centralised variants FERA and SER do not exist in the EU's regulatory realm. Moreover, they acknowledge that the structure of the European Central Bank ECB would be equivalent to the degree of autonomy enjoyed by a FERA (Thatcher and Coen, 2008).

Table 1 - Institutional Centralisation

\begin{tabular}{ll}
\hline FORM OF COOPERATION & CENTRALISATION \\
\hline 1 NRAs, no regulatory network & none \\
2 NIRA, informal regulatory network & very low \\
3 ERN, European regulatory network & low \\
4 ERA, networked regulatory agency & medium \\
5 FERA, centralised regulatory agency & high \\
(SER, single regulatory agency) & (very high)
\end{tabular}

Source: adapted from Thatcher and Coen (2008), SER in italics as a hypothetical outcome

A NIRA does not dispose of a formalised regulatory role according to EU secondary law, which is the case for an ERN. The next step in the centralisation hierarchy is to introduce an ERA whose mandate is also based on secondary law but is more encompassing than that of an ERN in that an ERA can make recommendations subject to a Commission proposal, and may adopt legally binding individual decisions. A FERA would be created in addition to national regulatory authorities by treaty amendment, and dispose of regulatory and implementation powers that apply throughout the EU and can be imposed on national authorities. Finally, a SER would entirely replace national regulators and, created by treaty amendment, be composed by EU officials rather than national representatives. Clearly, the institutional settings do not go beyond more or less formalised cooperation between national authorities in the case of NIRAs and ERNs. But also the ERA structure still adds a relatively thin layer at the supranational level where regulatory competencies remain circumscribed, and in particular cannot override the regulatory authority at national level. By contrast, a FERA can impose regulatory decisions on national authorities, and thus represents a truly centralised institutional arrangement. A SER is at this stage a merely hypothetical outcome. 
The literature on differentiated integration (Leuffen et al., 2013; Schimmelfennig, 2014; Schimmelfennig, 2016) provides a good starting point to capture the policy space in which EU agencies operate. Leuffen et al. (2013: 7-26) make a distinction between vertical and horizontal integration. Vertical integration refers to the centralisation of decision-making across policy areas, whereas horizontal integration captures the territorial scope of different policies (ibid.: 12). While I do not discard the effect of horizontal differentiation on the work of EU agencies, the focus here is on the degree to which policy-making is centralised, i.e. what Leuffen et al. call vertical differentiation. They draw on Börzel's work on the level and scope of European integration (2005: 221). In order to determine the degree of centralisation of the policy space in which an EU agency operates I will rely on Börzel's analysis of the level of integration, which is displayed in Table 2. She differentiates between five categories going from entirely national competencies to exclusive competencies for the EU, with three intermediary categories where competencies are shared. The right-hand column characterises the achieved degree of policy centralisation for each category.

Table 2 - Policy centralisation

\begin{tabular}{ll}
\hline POLICY-MAKING PROCEDURE & CENTRALISATION \\
\hline 1 competencies for all policy issues at national level & none \\
2 competencies for most policy issues at national level & low \\
3 competencies for policy issues split & medium \\
4 competencies for most policy issues at EU level & high \\
5 competencies for all policy issues at EU level & very high \\
\hline
\end{tabular}

Source: adapted from Börzel (2005: 221)

Outcomes of agencification in the European context

Agencification can result in four possible settings as displayed in Table 3, two of them with mixed outcomes, and two others where similar levels of institutional and policy centralisation combine. 


\begin{tabular}{lll}
\hline POLICY & low centralisation & high centralisation \\
\hline INSTITUTIONAL & low/low & low/high \\
low centralisation & "weak agency" \\
high centralisation & high/low & \\
& "strong agency"
\end{tabular}

Author's illustration

Let us consider the four settings in more detail. A low degree of institutional and policy centralisation would allow for considerable national control, and thus be most in line with the intergovernmental image of agencification (Egeberg and Trondal, 2016: 2). From a principal agent perspective (Aghion and Tirole, 1997; Moe, 1990) EU agencies or regulatory networks would thus mainly be the agents of the member states. An alternative perspective for this low level of centralisation on both dimensions is provided by the transnational image, where EU agencies or regulatory networks are assumed to be loosely coupled to both national and EUlevel institutions (Egeberg and Trondal, 2016: 2).

A mixed outcome which combines a low level of institutional and a high level of policy centralisation - which I call the "weak agency" scenario - should be of particular empirical relevance in the EU, given the legal and political limitations to agencification (Chamon, 2016). In this case the image of EU agencies acting as "inbetweeners" (Everson et al., 2014) appears relevant, assuming that a lack of centralised regulatory authority would accommodate national control but that, based on their policy competencies, supranational institutions would equally play a role. This scenario could also be interpreted along the lines of a supranational image (Egeberg and Trondal, 2016: 3). In a context where competencies for most policy issues are held at EU level, we could assume that EU agencies are closely tied to the European Commission in particular and form part of the EU's integrated administration (Egeberg et al., 2015; Jevnaker, 2015).

The third setting which combines fragmentation policy-wise with high centralisation institution-wise appears less intuitive for EU agencification. To prepare the path for further Europeanisation agencies would be required to act as "instruments of centralisation" (Majone, 
2005: 5). I call this the "strong agency" scenario where institutional centralisation would have to compensate for policy fragmentation. In the absence of policy centralisation the EU agency would, however, have to rely on member states in order to secure consistent implementation across levels. Agencies can therefore also be considered as inbetweeners in this constellation.

Finally, there is the most supranational option where strong levels of centralisation on both dimensions combine. It seems appropriate to think of this type of body as a trustee or fiduciary (Tesche, 2018; Majone, 2001; De Visscher et al., 2008). Fiduciaries dispose of a significant degree of authority and independence, as the major rationale for delegation is credible commitment. This motive has been considered to be particularly relevant for monetary policy and has served to justify central bank independence (Cukierman and Webb, 1995). In the EU context it is indeed the European Central Bank (ECB) which is the sole institution that acts in a mostly centralised policy space and disposes of a significant degree of independence (Tesche, 2020: 223; Leuffen et al., 2013: 22; Börzel, 2005).

\section{Case selection, data and structure of the comparison}

A structured focused comparison of agencification in the banking and electricity sector will serve to illustrate the value added of the analytical lens. Agencification in electricity constitutes a typical case for the EU setting, as it has followed an incremental process resulting in a networked agency. The European Banking Union (EBU), by contrast, bears some peculiarities both with respect to its sudden creation (Glöckler et al., 2017) and the achieved degree of centralisation, given that the ECB is entrusted with tasks in banking supervision (Tesche, 2020). The case selection strategy in this paper thus is to contrast a typical case with an outlier case for the universe of cases in the EU. Accordingly, the empirical discussion will put stronger emphasis on banking, also to pay tribute to the EBU's complex and diversified architecture.

The qualitative comparison draws on previous contributions in political science and law, as well as material gathered through document analysis and expert interviewing with representatives from national and European regulatory bodies. I have conducted 16 half-structured interviews with policy experts in France and Germany as well as at EU level: 7 on banking, out of which 2 in France, 2 in Germany, and 3 at EU level; and 9 on energy, out of which 2 in France, 2 in Germany and 5 at European level. In the following sections I will first trace the evolution of 
institutional and policy centralisation over time and then engage in a comparative mapping of the outcomes of agencification.

\section{The process of agencification in electricity and banking}

The shift of regulatory competencies towards the European level was initially slow and politically difficult in both sectors. Energy market creation and integration which kicked off in the 1990s was accompanied by a gradual, step-wise formalisation and centralisation of crossborder cooperation. Integration in the banking sector can be sub-divided into three phases: a first phase from the 1970s onwards where regulation mostly remained in the national realm, a second phase of integration based on soft governance and Comitology at the start of the new millennium; and a third phase after the economic and financial crisis which saw the creation of the EBU.

Institutional change - incremental versus big bang

Agencification in electricity is a typical process of "layering" and incremental change which in the EU context has been discerned in many other sectors (Thatcher and Coen, 2008). Institutional centralisation in the EBU, by contrast, qualifies as "punctuated change" (Glöckler et al., 2017: 1136).

Table 4 Institutional centralisation in electricity and banking

\begin{tabular}{|c|c|c|c|}
\hline & Electricity & Banking & \\
\hline $1 \mathrm{NRAs}$ & before 2000 & before 1977 & \\
\hline 2 NIRA & 2000 CEER (still exists) & 1977 High-level group & \\
\hline 3 ERN & 2003 ERGEG & 2003 CEBS & \\
\hline 4 ERA & 2011 ACER & 2011 EBA, 2015 SRB & \\
\hline 5 FERA & & 2014 ECB (SSM) & EBU \\
\hline
\end{tabular}

Author's illustration

The evolving structure of regulatory cooperation in the European electricity sector is well researched and has been widely discussed in the literature (Mathieu and Rangoni, 2019; Mathieu, 2020; Jevnaker, 2015; Rangoni and Zeitlin, 2020; Eberlein, 2008; Rangoni, 2019). A first wave of academic interest was triggered by the creation of a so-called forum process in 
1999 (Vasconcelos, 2001; Héritier, 2003; Eberlein, 2005). In order to facilitate the discussion about market integration the Commission in 1999 initiated the Electricity Regulatory Forum to be held in Florence. The so-called Florence Forum brought together policymakers, regulators, and stakeholders. While it failed to deliver concrete policy decisions, it fueled institutional change. In particular, it was conducive to the creation of an informal network of independent regulators (NIRA) with the establishment of the Council of European Energy Regulators (CEER) in 2000. The informal gathering of regulators inside the CEER, which exists until today, was subsequently complemented by formal structures with the introduction of the European Regulators Group for Electricity and Gas (ERGEG, created by Commission decision 2003/796 EC). As the second electricity directive gave regulators a policy mandate, ERGEG qualifies as an ERN. ERGEG was replaced by the Agency for the Cooperation of Energy Regulators (ACER) with the third energy package in 2009. ACER, created by regulation EC no. $713 / 2009$ started to operate in 2011. When proposing the third energy package the Commission had initially envisaged a strikingly weak role for the regulators' network, to function mainly as a consulting body with hardly any direct competencies (European Commission, 2007: 11-12, 25-27). NRAs inside the CEER therefore mobilised opposition to the proposal (CEER, 2008), and garnered support inside the European Parliament in support of a stronger agency (European Parliament, 2008: 33). This stance did however fail to receive political backing in the Council, given that member states sought to safeguard regulatory power within the national remits (Jevnaker, 2015: 930, 936). The Commission, along the lines of the famous 'Meroni doctrine' pointed to the constraints of delegating tasks to a single agency (Chamon, 2016: 208-209). In 2016, when proposing the Clean Energy Package, the Commission reiterated that the role of ACER " [...] is not the execution of delegated regulatory Commission competencies, but the coordination of the regulatory decisions of independent national regulators" (European Commission, 2016: 22). The Clean Energy Package, adopted throughout 2018 and 2019, will further enhance the role of ACER (regulation (EU) 2019/944), yet without unsettling the existing institutional architecture (Eckert and Eberlein, 2020: 68-69, 71). De facto ACER remains a relatively small supranational secretariat that relies heavily on the administrative capacity of national energy regulators. Regulatory cooperation in the energy sector thus followed an incremental path starting out with a NIRA (CEER) which was given 
tasks as an ERN (ERGEG), and then transformed into a European Regulatory Agency or ERA (ACER).

Cross-border cooperation of banking regulators emerged far earlier than in electricity, namely as a result of a first European directive adopted in 1977. In this context a high level-group of national banking regulators was created which was used for information exchange purposes, especially as far as banks holding operations in several member states were concerned (Grossman and Leblond, 2012: 194). The new millennium kicked off with some institutional innovation suggested by a group of experts chaired by Baron Alexandre Lamfalussy. The new architecture relied on Comitology to complement secondary law with technical implementing measures and provided for the creation of committees of national regulators specialised in banking, securities and insurance (Lastra, 2019: 11; De Visscher et al., 2008). These committees had a mandate to provide advice to the Commission, and developed joint interpretation recommendations, guidelines and standards. Furthermore, they functioned as platforms to exchange best practice (Coen and Salter, 2019: 120; Alford, 2006). The Committee of European Banking Supervisors (CEBS), created in 2004, assembled more than 50 national regulators, and entirely relied on their resources (Lastra, 2019: 12). Commentators argued that the structure did not prove particularly effective due to its complexity, the lack of a clear mandate between supervision and crisis management, as well as the "the interlocking of many national sources of authority" (Véron, 2007: 4). In 2011 another move to centralise regulatory oversight followed with the creation of three European Supervisory Authorities (ESAs) and the European Systemic Risk Board (ESRB), entrusted with micro- and macro-prudential supervision, respectively (Grossman and Leblond, 2012: 204-205). These ESAs replaced the aforementioned committees, i.e. CEBS was replaced by the European Banking Authority (EBA) which qualifies as an ERA. In its role as a microprudential supervisor EBA conducted stress tests and could issue binding measures addressed to banks. Moreover, it held a regulatory mandate in providing substantial input to the Single Rulebook to govern the Single Financial Market (Quaglia, 2013; Lastra, 2019: 13; Buckley et al., 2012). Finally, the agency's enforcement powers were supposed to contribute to a harmonised implementation of European rules by national authorities, and to that end EBA could issue individual supervisory decisions (Scholten and van Rijsbergen, 2019: 1225; Coen and Salter, 2019: 121).

From 2007 onwards the economic and financial crisis opened a new window of opportunity for institutional change, which clearly departed from the "tradition of gradual institutional 
innovations observed in EMU so far" (Glöckler et al., 2017: 1146). There is widespread consensus both in the legal (e.g. Tröger, 2014) and political science literature (e.g. Epstein and Rhodes, 2018; Epstein and Rhodes, 2016) as to the degree to which authority has been centralised in this context. The EBU relies on three pillars, the Single Supervisory Mechanism (SSM), the Single Resolution Mechanism (SRM), and the European Deposit Scheme (EDIS), out of which the first two have so far been realised. The SSM was created with a Council regulation (no. 1024/2013) which delegated supervisory powers to the ECB based on article 127(6) of the Treaty on the Functioning of the European Union (TFEU). The choice for this treaty base and entrusting the ECB rather than the EBA as the supervisory authority proved to be the most solid option legally speaking - especially in view of the constraints encountered in expanding an EU agency's mandate - and moreover was politically opportune (Glöckler et al., 2017: 1147). The SSM comprises the ECB and the national supervisory authorities of the countries participating in the EBU. Institution-wise, the European layer of the SSM, i.e. the ECB, qualifies as a Federal European Regulatory Agency (FERA). As the single supervisor the ECB holds sole bank licensing authority and directly supervises the largest banks in the EU according to the criteria laid down in the Council regulation creating the SSM (article 6 regulation (EU) no. 1024/2013). The ECB directly supervises "significant institutions" (SIs), whereas "less significant institutions" (LSIs) are subject to national oversight. In its supervisory functions, the ECB is supported by Joint Supervisory Teams (JSTs) and national Competent Authorities (NCAs). The ECB does, however, hold powers of last resort and can take over banking supervision of LSIs where it sees a need to ensure consistent application of supervisory standards.

The second pillar, the SRM, exhibits a far lower degree of institutional centralisation and incorporates strong intergovernmental features (Epstein and Rhodes, 2018: 205; Epstein and Rhodes, 2016: 429). Member states were reluctant to cede resolution powers, and were opposed to have either the ECB or the Commission hold respective powers (Donnelly and Asimakopoulos, 2019: 8). In response to such concerns the introduction of the SRM was driven by "political opportunism" (Mayes, 2017), taking on board diverging policy preferences such as those of France and Germany (Schild, 2018). There was also no obvious treaty base for the delegation of powers in this area, and at the time of the EBU's creation a treaty change was politically not feasible (Glöckler et al., 2017). Policymakers thus followed the Commission's suggestion to use article 114 TFEU for measures adopted in the context of the functioning of the Single European Market, a choice which continues to be subject to controversy (Epstein 
and Rhodes, 2016: 427; Zavvos and Kaltsouni, 2015: 8). The Single Resolution Fund, by contrast, has not been established based on EU law but on the basis of an international agreement. This allows the largest euro area member states to retain control (Asimakopoulos, 2018). Moreover, mutualisation inside the SRF is a very gradual process which envisages full coverage at a (rather unambitious) level of 55 billion euros not earlier than 2024 (Véron, 2015: 11-13). While the Single Resolution Board (SRB) has been set up as an EU agency, its statutes set it apart as "a specific Union agency with a specific structure, corresponding to its specific tasks, and which departs from the model of all other agencies of the Union" (recital 31 of regulation (EU) no 806/2014). The agency's institutional design keeps supranational, and especially the EP's control at a minimum (Vos, 2018b: 60, 63, 64). The SRB holds regulatory powers such as setting minimum requirements for own funds and eligible liabilities (MREL), to choose and decide on the use of resolution tools, and to trigger resolution jointly with the ECB. The decision-making architecture in the SRM features a stronger degree of decentralisation at both supranational and national level (Zavvos and Kaltsouni, 2015: 25). The SRB is sharing powers with the Commission as well as the Council, and in implementation closely cooperates with the NRAs to which it can issue instructions.

\section{Paths of policy centralisation}

The policy space in which these EU regulatory bodies operate has evolved quite differently in the two sectors. Electricity markets have been liberalised and integrated in a gradual, step-wise process since the 1990s, and European regulation of market and network related aspects can rely on a relatively solid EU policy framework by now. Banking regulation was for a long time unfinished business, and the sudden creation of a new layer of supranational supervision did not come along with an equal degree of institutional centralisation.

Table 5 - Policy centralisation in electricity and banking

\begin{tabular}{lll}
\hline & Electricity & Banking \\
\hline 1 national & until 1951 & until 1977 \\
2 most national & 1952 (ECSC), 1958 (Euratom) & $1977\left(1^{\text {st }}\right.$ dir. $), 1989\left(2^{\text {nd }}\right.$ dir. $)$ \\
3 split & $1996\left(1^{\text {st }}\right.$ dir. $), 2003\left(2^{\text {nd }}\right.$ dir. $)$ & 2001 (Lamf. $) 2014,19$ (BRRD I,II) \\
4 most EU & $2009\left(3^{\text {rd }}\right.$ dir., TFEU) $2019\left(3^{\text {rd }}\right.$ dir. $)$ & 2013 (SSMR $)$ \\
5 EU & - & -
\end{tabular}


Energy policy issues were at the heart of European integration already in the founding days of the European Communities with the creation of the European Coal and Steel Community (ECSC) and the Euratom treaty, yet a European energy policy did only emerge over the last three decades (previously discussed by Eckert, 2016; Eckert, 2015: chapter 4). Market integration kicked off in the mid-1990s with EC-directive 96/92, which still left ample leeway to member states policy choices regarding access regimes and network ownership (Eberlein, 2001). The second electricity directive (2003/54/EC) narrowed the range of options for the member states on a number of issues, for instance by making the introduction of an independent sector regulator mandatory, as well as by imposing regulated access to the electricity network. 2009 marked the adoption of another round of secondary legislation, but also the entry into force of the Treaty of Lisbon which introduced a dedicated chapter on energy policy (article 4 TFEU). Energy policy is a mixed competence and as such does not, for instance, touch upon policy choices concerning the energy mix (article 194 TFEU). The key controversy around the third energy package, adopted the same year, evolved around the issue of ownership unbundling, an option fervently opposed by France and Germany who wanted to safeguard their model of vertical integration. In the face of such opposition, the Commission used its competition policy powers strategically, notably by conducting a sector inquiry (Eikeland, 2011; Eberlein, 2012). The energy package, composed of several regulatory measures accompanying the electricity directive (2009/72/EC), left member states with a choice as to different unbundling schemes so that infrastructure governance varies significantly across the EU (Eckert, 2019: 186-189; Meletiou et al., 2018). The third package created new policy competencies on network related cross-border issues and mandated a newly created European Network of Transmission System Operators in Electricity (ENTSO-E) with the task to draft network codes (Jevnaker, 2015; Eckert, 2019: chapter 6). The fourth energy package, better known as the "Clean Energy" package, was adopted in May 2019. This time around the major political controversy was about introducing an additional regional level of regulatory oversight. While the Commission had proposed to introduce so-called Regional Operational Centers (ROCs), the less ambitious solution of Regional Coordination Centres (RCCs) was chosen instead. Four rounds of secondary legislation and re-regulation have brought about a policy framework which on issues of market creation and market integration, notably where crossborder network-related and infrastructure issues are concerned, is mostly European (see Table $5)$. 
European banking regulation had remained unfinished business for several decades (Grossman and Leblond, 2012). The 1977 directive established home country control, while a second directive (introduced in 1989, coming into effect from 1993) to a significant extent relied on the principle of mutual recognition. Post-crisis a first move towards European micro- and macroprudential supervision in 2011 was followed by the creation of the EBU's first two pillars with the adoption of the SSM regulation (SSMR) in 2013 and the Banking Recovery and Resolution Directive (BRRD) as well as the Single Resolution Mechanism Regulation (SRMR) in 2014. The resolution framework was revised in 2019 (BRRD II). In essence, the SSM was deemed to break the sovereign-bank nexus. The BRRD framework introduced standards for bank resolution for all EU member states (including those who are not participating in the EBU), while the SRMR provides its binding procedural and substantive framework. Views diverge as to the degree to which the EBU can rely on policy centralisation. Epstein and Rhodes have argued that with the creation of the EBU we witness an "emerging centralized state, based on policy harmonization" (2018: 207). They point to the extraordinary powers of the ECB which as a single supervisor can smooth out credit conditions across the Eurozone, whereas national authorities can no longer offer national banks supervisory forbearance (ibid. , 2018: 215). Ferran and Babis, in their legal analysis, caution that centralised supervision in the SSM "relies on a partially harmonized rulebook" (2013: 285). Similarly, Lastra observes that the rulebook falls short of harmonisation where it relies on soft law and guidelines or allows for national options and discretions (2019: 13). Kudrna and Puntscher Riekmann provide compelling evidence that the use of such options and discretions constitutes a persisting source of policy fragmentation (2018). Moreover, national competent authorities (NCAs) continue to play a critical function in prudential supervision given multinational banks' choice to either establish subsidiaries, subject to supervision by the host country, or branches, subject to supervision by the home country. The single supervisor lacks the competencies to override substantive differences in prudential regulation of both types of cross-border activities (Tröger, 2014: 14, 20-21). It is fair to conclude that even the first and most centralised pillar leaves significant room to regulatory divergence and discretion. In comparison to single supervision the policy debate on resolution was, from the outset, less advanced (Gros and Schoenmaker, 2014). Legal competencies relevant for the SRM are split across levels: resolution is covered by EU secondary legislation (BRRD), liquidation by national insolvency law, the use of public funds in resolution by the BRRD and state aid law, the use of public funds in liquidation by state aid law solely (Merler, 2017: 4). The European Commission (article 19 of SRMR) is in charge of any state or fund (through the SRF) aid granted under resolution, and thus holds the 
power to impose conditions for the restructuring of banks (Zavvos and Kaltsouni, 2015: 20-22). By contrast, banks would face different insolvency proceedings across countries (Merler, 2017: 16), and government could be tempted to amend the ordinary insolvency framework where they see fit. What is more, the possibility to have national insolvency is seen as a disincentive to implement the resolution framework at all (Donnelly and Asimakopoulos, 2019: 9). Overall the first, but especially the second pillar of the EBU are characterised by a striking degree of legal fragmentation and policy discretion.

The fact that so far only Eurozone countries participate in the EBU further complicates its functioning and solicits sophisticated procedures in supervisory practice (European Central Bank, 2018: 17, 30-31). This dimension of horizontal differentiation has been comprehensively covered in Schimmelfennig's analysis of the EBU architecture (2016), and is as such not the focus in this paper. It is, however, important to point out that the creation of the EBU came along with a shift from the single market logic towards the Eurozone context for a variety of reasons (Glöckler et al., 2017: 1146). We have already seen that this shift was more pronounced for the SSM where powers are delegated towards the ECB, while the second pillar in legal terms still makes use of single market prerogatives. While the Single Rulebook and the BRRD are deemed to cover both EBU and non-EBU member states, the expectation is that de facto the regulatory gap between the two will grow as the former will be subject to the ECB's "interpretation of harmonised banking regulation" (Tröger, 2014: 34), and the latter not. There is furthermore a dividing line not only between EU and Eurozone countries, but moreover between those (mostly Southern) Eurozone countries advocating risk-sharing policies versus those (mostly Northern) Eurozone countries promoting risk reduction (Epstein and Rhodes, 2018; Beach et al., 2020). The line of division within the Eurozone to some observers is the more pertinent one (Interview NCA, 2020; Interview EBA, 2020).

\section{Mapping outcomes: identifying the misfits}

The achieved degree of institutional and policy centralisation (each on a scale from 1-5) is summarised in Table 6. Agencification in both sectors initially pursued a typical path (grey shaded areas) which was discontinued in banking with the creation of the EBU (dark shaded areas). The achieved outcomes diverge in line with what I have dubbed the "strong agency" versus "weak agency" solution in this paper: limited institutional centralisation combines with 
a pronounced degree of policy centralisation in electricity; an unseen level of centralised supervisory authority is not to the same extent matched by policy harmonisation in banking.

Table 6 Agencification in Banking and Electricity



Author's illustration (banking regulation in italics until 2013, EBU in bold)

The political debates around ACER's role in electricity regulation sum up to what Ferran and Babis have identified as a standard vision of banking regulation which was "usually viewed as harmonized, and decentralized supervision has been seen as the main problem" (2013: 285). The institutional architecture of energy regulation proved controversial in the subsequent rounds of policy formulation during which the European Parliament (2008: 33) voiced its support for a stronger agency, while the member states voiced legal and political concerns against this option (Jevnaker, 2015: 930, 936). It is worth noting that the European Commission's stance did not reproduce these classical patterns of supranational versus intergovernmental positioning, advocating a rather weak role of networked cooperation amongst national regulators (European Commission, 2007: 11-12, 25-27). By contrast, the Commission promoted a relatively strong role of the network bringing together transmission system operators (TSOs) inside ENTSO, a standpoint which was also based on a positive track record of the TSOs role in market integration and an achieved level of mutual trust (Eckert, 2019: 197). The political alliances formed do not entirely match with the classical supranational image (Egeberg and Trondal, 2016: 3) where the expectation is for EU agencies and the 
European Commission to form close ties (Egeberg et al., 2015; Jevnaker, 2015). Rather, the integration dynamics in energy regulation have seen a lateral shift towards private authority as an "escape route" (Eckert and Eberlein, 2020: 62-63) in order to fill in regulatory gaps on crossborder, infrastructure-related issues.

Similarly, one could argue that delegation to the ECB was the only way out when facing a lack of legally and politically viable alternatives. The degree of independence of the ECB in monetary policy should, however, not be taken for granted in the supervisory context (Ferran and Babis, 2013: 270; Table 6 differentiates between the ECB's role in banking and monetary policy accordingly). Contrary to previous arguments on the ECB's supervisory role (Tesche, 2020) I would thus posit that the ECB is not acting as a trustee to the same extent as it does in the monetary context. Regulatory authority in the second pillar in particular does not add up to this supranational image, as it is very much a "hybrid" (Vos, 2018a; Everson et al., 2014) arrangement resulting from supranational and intergovernmental dynamics. While the initial proposal of the Commission had attributed important policy and decision-making powers to itself, the final outcome incorporated a significant level of member state control (Zavvos and Kaltsouni, 2015: 22-23). The few cases where the SRM has thus far been relevant (Donnelly and Asimakopoulos, 2019; Culpepper and Tesche, 2020; Donnelly, 2018) justify initial concerns that national discretion could undermine its proper functioning (Zavvos and Kaltsouni, 2015: 26-28), and illustrate how leading economies can control the resolution framework thanks to its "nationalised character" (Asimakopoulos, 2018).

\section{Conclusions}

This working paper has approached agencification as a double process of institutional and policy centralisation. I find that these two dimensions do not necessarily coincide and that the "weak agency" model constitutes the typical outcome of EU agencification. This outcome results from a process of institutional centralisation which develops incrementally and remains limited, yet is accompanied by substantial policy centralisation. The "strong agency" model, by contrast, is characterised by a high degree of institutional centralisation which is not to the same extent matched by policy centralisation. The comparative case study discusses electricity and banking regulation. The lengthy process of agencification in energy policy has resulted in a weak level of institutional centralisation. The sudden creation of the EBU, by contrast, came along with an extraordinary shift of supervisory authority towards the European level. While 
this shift has frequently been discussed as an example of a fiduciary relationship or trusteeship, the paper draws our attention to the degree to which the policy landscape remains fragmented even in the supposedly most centralised first pillar of the EBU. Moreover, it systematically works out variation between the supervision and resolution pillars. In view of these mixed or hybrid outcomes it is most accurate to conceptualise EU agencies as inbetweeners (Vos, 2018a; Everson et al., 2014).

The suggested framework could usefully be applied to analyse other EU agencies in order to further develop the promises and pitfalls of these two models of agencification. In the current context of crisis a weak agency lacks the competencies in order to respond swiftly to arising policy problems. ACER, for that matter, has not been a visible actor but may see its policy mandate altered in view of unanticipated shifts on global energy markets and the implications of national as well as EU recovery measures for energy transformation. Joint banking supervision, by contrast, can sustain a coordinated approach, for instance by granting suspension form regulatory requirements and operational relief to facilitate banks' crisis responses (ECB, 2020), but also for various recovery measures such as launching new credit or equity lines (Boot et al., 2020). As in the previous crisis, however, the strong agency runs the risk to disappoint in view of great expectations and persistently diverging national policies.

\section{References}

Aghion P and Tirole J. (1997) Formal and Real Authority in Organizations. Journal of Political Economy 105(1): 1-29.

Alford D. (2006) The Lamfalussy Process and EU Bank Regulation: Another Step on the Road to Pan-European Bank Regulation? Annual Review of Banking \& Finance Law 25: 389442.

Asimakopoulos IG. (2018) International law as a negotiation tool in Banking Union; the case of the Single Resolution Fund. Journal of Economic Policy Reform 21(2): 118-131.

Beach D, Schäfer D and Smeets S. (2020) The Past in the Present-The Role of Analogical Reasoning in Epistemic Learning About How to Tackle Complex Policy Problems. Policy Studies Journal early view.

Blauberger $\mathrm{M}$ and Rittberger B. (2015) Conceptualizing and theorizing EU regulatory networks. Regulation \& Governance 9(4): 367-376.

Boot A, Carletti E, Kotz H-H, et al. (2020) Corona and Financial Stability 3.0: Try equity -risk sharing for companies, large and small. SAFE Policy Letter 81: 1-5.

Börzel TA. (2005) Mind the gap! European integration between level and scope. Journal of European Public Policy 12(2): 217-236.

Buckley J, Howarth D and Quaglia L. (2012) Internal Market: The Ongoing Struggle to 'Protect' Europe from Its Money Men. Journal of Common Market Studies 50(2): 99115.

CEER. (2008) Making the 3rd energy package proposal more effective. Press Release. Brussels: Council of European Energy Regulators. 
Chamon M. (2016) EU Agencies: Legal and Political Limits to the Transformation of the EU Administration, Oxford: Oxford University Press.

Coen D and Salter J-P. (2019) Multilevel regulatory governance: Establishing bank-regulator relationships at the European Banking Authority. Business and Politics 22(1): 113-134.

Coen D and Thatcher M. (2008) Network Governance and Multi-level Delegation: European Networks of Regulatory Agencies. Journal of Public Policy 28(1): 49-71.

Cukierman A and Webb SB. (1995) Political influence on the central bank: international evidence. World Bank Economic Review 6(3): 397-423.

Culpepper PD and Tesche T. (2020) Death in Veneto? European banking union and the structural power of large banks. Journal of Economic Policy Reform early view.

De Visscher C, Maiscocq O and Varone F. (2008) The Lamfalussy Reform in the EU Securities Markets: Fiduciary Relationships, Policy Effectiveness and Balance of Power. Journal of Public Policy 28(1): 19-47.

Donnelly S. (2018) Liberal Economic Nationalism, Financial Stability, and Commission Leniency in Banking Union. Journal of Economic Policy Reform 21(2): 159-173.

Donnelly S and Asimakopoulos IG. (2019) Bending and Breaking the Single Resolution Mechanism: The Case of Italy. Journal of Common Market Studies early view.

Eberlein B. (2001) To Regulate or not to Regulate Electricity. Explaining the German Sonderweg in the EU Context. Journal of Network Industries 2(3): 353-384.

Eberlein B. (2005) Regulation by Cooperation: The Third Way in Making Rules for the Internal Energy Market. In: Cameron P (ed) Legal Aspects of EU Energy Regulation. Implementing the new directives on electricity and gas across Europe. 59-88.

Eberlein B. (2008) The Making of the European Energy Market: The Interplay of Governance and Government. Journal of Public Policy 28(1): 73-92

Eberlein B. (2012) Inching Towards a Common Energy Policy: Entrepreneurship, Incrementalism, and Windows of Opportunity. In: Richardson J (ed) Constructing a Policy-Making State? Policy Dynamics in the EU. Oxford: Oxford University Press, 147-169.

ECB. (2020) ECB Banking Supervision provides temporary capital and operational relief in reaction to coronavirus. Frankfurt: ECB.

Eckert S. (2015) The Social Face of the Regulatory State. Reforming Public Services in Europe, Manchester: Manchester University Press.

Eckert S. (2016) The Governance of Markets, Sustainability and Supply. Toward a European Energy Policy. Journal of Contemporary European Research 12(1): 502-517.

Eckert S. (2019) Corporate Power and Regulation. Consumers and the Environment in the European Union, London: Palgrave.

Eckert S and Eberlein B. (2020) Private authority in tackling cross-border issues. The hidden path of integrating European energy markets. Journal of European Integration 42(1): $59-75$.

Egeberg M and Trondal J. (2016) Agencification of the European Union Administration: Connecting the Dots. TARN Working Paper 1(2016).

Egeberg M and Trondal J. (2017) Researching European Union Agencies: What Have We Learnt (and Where Do We Go from Here)? Journal of Common Market Studies 55(4): 675-690.

Egeberg M, Trondal J and Vestlund NM. (2015) The quest for order: unravelling the relationship between the European Commission and European Union agencies. Journal of European Public Policy 22(5): 609-629.

Eikeland PO. (2011) The Third Internal Energy Market Package: New Power Relations among Member States, EU Institutions and Non-state Actors? Journal of Common Market Studies 49(2): 243-263. 
Epstein RA and Rhodes M. (2016) The Political Dynamics Behind Europe's New Banking Union. West European Politics 39(3): 415-437.

Epstein RA and Rhodes M. (2018) From Governance to Government: Banking Union, Capital Markets Union and the new EU. Competition \& Change 22(2): 205-224.

European Central Bank. (2018) SSM Supervisory Manual. European banking supervision: functioning of the SSM and supervisory approach. Frankfurt am Main: European Central Bank.

European Commission. (2007) Proposal for a Regulation of the European Parliament and of the Council establishing a European Union Agency for the Cooperation of Energy Regulators. COM (2007) 530 final. Brussels: European Commission.

European Commission. (2016) Proposal for a Regulation of the European Parliament and of the Council on the internal market for electricity. COM (2016) 861 final. Brussels: European Commission.

European Parliament. (2008) Report on the proposal for a regulation of the European Parliament and of the Council amending Regulation (EC) No 1228/2003 on conditions for access to the network for cross-border exchanges in electricity (COM (2007)0531-C60320/2007-2007/0198(COD)) A6-0228/2008. Brussels: Committee on Industry, Research and Energy. Rapporteur Alejo Vidal-Quadras.

Everson M, Monda C and Vos E. (2014) European Agencies in Between Institutions and Member States: Wolters Kluwer Law \& Business.

Ferran E and Babis VSG. (2013) The European Single Supervisory Mechanism. Journal of Corporate Law Studies 13(2): 255-285.

Glöckler G, Lindner J and Salines M. (2017) Explaining the sudden creation of a banking supervisor for the euro area. Journal of European Public Policy 24(8): 1135-1153.

Groenleer M. (2009) The autonomy of European Union Agencies, Delft: Eburon.

Groenleer M. (2011) Regulatory governance in the European Union: the role of committees, agencies and networks. In: Levi- Faur D (ed) Handbook on the Politics of Regulation. Cheltenham: Edward Elgar, 548-561.

Gros D and Schoenmaker D. (2014) European Deposit Insurance and Resolution in the Banking Union. Journal of Common Market Studies 52(3): 529-546.

Grossman E and Leblond P. (2012) Financial Regulation in Europe: From the Battle of the Systems to a Jacobinist EU. In: Richardson J (ed) Constructing a Policy-Making State? Policy Dynamics in the EU. Oxford: Oxford University Press.

Héritier A. (2003) New Modes of Governance in Europe: Increasing Political Capacity and Policy Effectiveness? In: Börzel TA and Cichowski RA (eds) The State of the European Union. Law, Politics, and Society. Oxford: Oxford University Press, 105-126.

Interview EBA. (2020) policy coordination and communication expert, EBA, Paris, 3 March 2020.

Interview NCA. (2020) banking resolution expert, ACPR, Paris, 4 March 2020.

Jevnaker T. (2015) Pushing administrative EU integration: the path towards European network codes for electricity. Journal of European Public Policy 22(7): 927-947.

Kudrna Z and Puntscher Riekmann S. (2018) Harmonizing National Options and Discretions in the EU Banking Regulation. Journal of Economic Policy Reform 21(2): 144-158.

Lastra RM. (2019) Multilevel Governance in Banking Regulation. In: Chiti MP and Santoro V (eds) The Palgrave Handbook of European Banking Union Law. London: Springer International Publishing, 3-17.

Leuffen D, Rittberger B and Schimmelfennig F. (2013) Differentiated Integration. Explaining Variation in the European Union, Basingstoke: Palgrave Macmillan.

Levi-Faur D. (2011) Regulatory networks and regulatory agencification: towards a Single European Regulatory Space. Journal of European Public Policy 18(6): 810-829. 
Maggetti M and Gilardi F. (2011) The policy-making structure of European regulatory networks and the domestic adoption of standards. Journal of European Public Policy 18(6): 830-847.

Majone G. (2001) Two Logics of Delegation : Agency and Fiduciary Relations in EU Governance. European Union Politics 2(1): 103-122.

Majone G. (2005) Dilemmas of European Integration, Oxford: Oxford University Press.

Mathieu E. (2020) Functional stakes and EU regulatory governance: temporal patterns of regulatory integration in energy and telecommunications. West European Politics 43(4): 991-1010.

Mathieu E and Rangoni B. (2019) Balancing experimentalist and hierarchical governance in European Union electricity and telecommunications regulation: A matter of degrees. Regulation \& Governance 13(4): 577-592.

Mayes DG. (2017) Banking union: The disadvantages of opportunism. Journal of Economic Policy Reform 21(2): 132-143.

Meletiou A, Cambini C and Masera M. (2018) Regulatory and ownership determinants of unbundling regime choice for European electricity transmission utilities. Utilities Policy 50: $13-25$.

Merler S. (2017) Critical functions and public interest in banking services: Need for clarification? Banking Union Scrutiny. In-depth Analysis. Requested by the ECON committee. Economic Governance Support Unit. Brussels: European Parliament.

Moe TM. (1990) Political Institutions. The Neglected Side of the Story. Journal of Law, Economics and Organization 6(Special Issue): 213-253.

Ossege C. (2015) Driven by Expertise and Insulation? The Autonomy of European Regulatory Agencies. Politics and Governance 3(1): 13.

Quaglia L. (2013) Financial regulation and supervision in the European Union after the crisis. Journal of Economic Policy Reform 16(1): 17-30.

Rangoni B. (2019) Architecture and policy-making: comparing experimentalist and hierarchical governance in EU energy regulation. Journal of European Public Policy 26(1): 63-82.

Rangoni B and Zeitlin J. (2020) Is experimentalist governance self-limiting or self-reinforcing? Strategic uncertainty and recursive rulemaking in European Union electricity regulation. Regulation \& Governance early view.

Schild J. (2018) Germany and France at Cross Purposes: The Case of Banking Union. Journal of Economic Policy Reform 21(2): 102-117.

Schimmelfennig F. (2014) Differentiated Integration Before and After the Crisis. In: Cramme O and Hobolt SB (eds) Democratic Politics in a European Union Under Stress. Oxford: Oxford University Press, 120-134.

Schimmelfennig F. (2016) A differentiated leap forward: spillover, path-dependency, and graded membership in European banking regulation. West European Politics 39(3): 483-502.

Scholten M and van Rijsbergen M. (2019) The Limits of Agencification in the European Union. German Law Journal 15(7): 1223-1255.

Tarrant A and Kelemen RD. (2017) Reconceptualizing European Union regulatory networks: A response to Blauberger and Rittberger. Regulation \& Governance 11(2): 213-222.

Tesche T. (2018) The troika is dead, long live the domestic troikas? Varieties of technocracy and the diffusion of national fiscal councils in the European Union: Agents, trustees or orchestrators of fiscal discipline? TARN Working Paper 3(2018).

Tesche T. (2020) Supranational agency and indirect governance after the Euro crisis: ESM, ECB, EMEF and EFB. Journal of Contemporary European Studies 28(1): 114-127.

Thatcher M and Coen D. (2008) Reshaping European Regulatory Space: An Evolutionary Analysis. West European Politics 4: 806-836. 
Tröger TH. (2014) The Single Supervisory Mechanism - Panacea or Quack Banking Regulation? SAFE Working Paper Series 27: 1-45.

Vasconcelos J. (2001) Cooperation between Energy Regulators in the European Union. In: Henry C, Matheu M and Jeunemaître A (eds) Regulation of Network Utilities. The European Experience. Oxford: Oxford University Press, 284-289.

Véron N. (2007) Is Europe Ready for a Major Banking Crisis? Bruegel policy brief 2007/03 2007(3).

Véron N. (2015) Europe's Radical Banking Union. Bruegel Essay and Lecture Series: 1-60.

Vos E. (2018a) EU agencies on the move: challenges ahead. Swedish Institute for European Policy Studies 2018(1).

Vos E. (2018b) EU Agencies, common approach and Parliamentary Scrutiny. european Implementationi Assessment. In: Korver R (ed) EPRS. European Parliamentary Research Service. Brussels: European Parliament.

Wonka A and Rittberger B. (2010) Credibility, Complexity and Uncertainty: Explaining the Institutional Independence of 29 EU Agencies. West European Politics 33(4): 730-752.

Zavvos GS and Kaltsouni S. (2015) The Single Resolution Mechanism in the European Banking Union: Legal foundation, governance structure and financing. In: Haentjens $\mathrm{M}$ and Wessels B (eds) Research Handbook on Crisis Management in the Banking Sector. Edward Elgar Publishing, 117-149. 


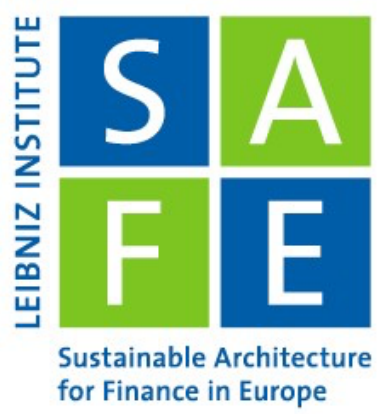

\section{Recent Issues}

No. 277 Dominique M. Lammer, Tobin Hanspal, Andreas Hackethal

No. 276 Massimiliano Caporin, Loriana Pelizzon, Alberto Plazzi

No. 275 Loriana Pelizzon, Max Riedel, Zorka Simon, Marti Subrahmanyam

No. 274 Christopher Busch, Alexander Ludwig

No. 273 Di Bu, Tobin Hanspal, Yin Liao, Yong Liu

No. 272 Christine Laudenbach, Benjamin Loos, Jenny Pirschel, Johannes Wohlfart

No. 271 Pietro Dindo, Andrea Modena, Loriana Pelizzon

No. 270 Mario Bellia, Kim Christensen, Aleksey Kolokolov, Loriana Pelizzon, Roberto Renó

No. 269 Ester Faia, Maximilian Mayer, Vincenzo Pezone

No. 268 Lorenzo Maria Levati, Marie Lalanne

No. 267 Wataru Kureishi, Hannah PaulePaludkiewicz, Hitoshi Tsujiyama, Midori Wakabayashi

No. 266 Benjamin Bluhm, Jannic Cutura

No. 265 Christian Schlag, Julian Thimme, Rüdiger Weber

No. 264 Hengjie Ai, Jun E. Li, Kai Li, Christian Schlag
Who Are the Bitcoin Investors? Evidence from Indirect Cryptocurrency Investments

Does Monetary Policy Impact International Market Co-Movements?

Collateral Eligibility of Corporate Debt in the Eurosystem

Higher-Order Income Risk Over the Business Cycle

Financial Literacy and Self-Control in FinTech: Evidence from a Field Experiment on Online Consumer Borrowing

The Trading Response of Individual Investors to Local Bankruptcies

Risk Pooling, Leverage, and the Business Cycle

High-Frequency Trading During Flash Crashes: Walk of Fame or Hall of Shame?

The Value of Firm Networks: A Natural Experiment on Board Connections

The Impact of Job Referrals on Employment Outcomes in Top Corporate Positions

Time Preferences over the Life Cycle

Econometrics at Scale: Spark Up Big Data in Economics

Implied Volatility Duration: A Measure for the Timing of Uncertainty Resolution

The Collateralizability Premium 